\title{
Ksiądz protoprezbiter płk Bazyli Martysz (1874-1945) - naczelny kapelan wyznania prawosławnego w Wojsku Polskim
}

\author{
Jerzy Grzybowski \\ Katedra Studiów Interkulturowych Europy Środkowo-Wschodniej, Wydział Lingwistyki Stosowanej, Uniwersytet Warszawski \\ Warszawa, Polska \\ jgrzybowski@uw.edu.pl
}

\begin{abstract}
Jerzy Grzybowski, Fr. Protopriest Colonel Bazyli Martysz (1874-1945) chief chaplain of the Orthodox Church in the Polish Army, Elpis, 20 2018: 41-48.

Abstract: The article deals with the fate of Fr. Protopriest Colonel Bazyli Martysz, who was a chaplain in the armed forces of the Second Republic. Based on the archival sources, the Author discusses the successive stages of his pastoral ministry in the army. His life's path as a soldier and priest is presented against the background of the political events that took place in the country at that time.

Streszczenie: Artykuł traktuje o losie ks. protoprezbitera płk Bazylim Martyszu, kapelanie wojskowym, organizatorze duszpasterstwa wojskowego wyznania prawosławnego w odrodzonym Wojsku Polskim. Duchowny znakomicie zapisał się w dziejach Kościoła prawosławnego i sił zbrojnych II Rzeczypospolitej. W oparciu o źródła archiwalne Autor omawia kolejne etapy jego służby duszpasterskiej w wojsku. Szlaki żołnierski i kapłański duchownego zostały ukazane na tle wydarzeń politycznych, które wówczas się dokonywały w kraju.
\end{abstract}

Keywoods: Orthodox, Polish Army, military chaplaincy, chaplain

Słowa kluczowe: prawosławie, Wojsko Polskie, duszpasterstwo wojskowe, kapelan

Dzieje Kościoła prawosławnego są ściśle związane z historią Polski. Wielu wyznawców prawosławia dało się poznać jako gorący patrioci - obrońcy niepodległości i granic Rzeczypospolitej. Wśród obywateli polskich wyznania prawosławnego, którzy dobrze zapisali się w dziejach oręża polskiego, należy wymienić ks. protoprezbitera płk Bazylego Martysza. W dotychczasowej literaturze przedmiotu pojawiały się większe lub mniejsze przyczynki dotyczące historii życia kapelana. Mimo to postać ojca Bazylego nie była dotychczas przedmiotem szerszych badań naukowych. Celem niniejszej publikacji jest próba przedstawienia działalności ks. B. Martysza jako naczelnego kapelana prawosławnego w siłach zbrojnych II Rzeczypospolitej. W oparciu o dotąd niewykorzystane źródła archiwalne dokonamy analizy prowadzonej przez niego posługi duszpasterskiej oraz aktywności organizacyjnej i religijno -wychowawczej w wojsku zarówno w okresie wojny polsko-bolszewickiej, jak i w czasie pokoju.

Bazyli Martysz urodził się 20 lutego 1874 r. w miejscowości Szechowice w powiecie hrubieszowskim. Przyszły kapelan przyszedł na świat w rodzinie Aleksandra i Katarzyny (z d. Korolczuk). Niestety, w źródłach zachowało się nie wiele informacji na temat jego młodości. Wiemy, że wraz z ojcem w dzieciństwie odbył podróż do Stanów Zjednoczonych. W 1897 r. ukończył Seminarium Duchowne w Chełmie. Następnie był katechetą w Suwałkach, Łukowie i Sosnowcu. Od 1 czerwca 1898 r. był również psalmistą w parafii w Łukowie. 2 lipca 1900 r. zawarł związek małżeński z Olgą Nowik. 6 grudnia 1900 r. otrzymał świę- cenia diakońskie, zaś 10 grudnia tegoż roku - kapłańskie. W tymże roku wraz z żoną wyjechał do Stanów Zjednoczonych $\mathrm{w}$ celu podjęcia pracy misyjnej. Początkowo był misjonarzem na Alasce i Wyspach Aleuckich (wyspy Afognak i Kodiak). Podczas pobytu na Alasce duchowny prowadził dziennik, który stanowi cenne źródło na temat działalności misyjnej ojca Bazylego na ziemi amerykańskiej. Wiemy, że pierwsza parafia ks. Martysza obejmowała trzy wyspy: Afognak, Spruce i Woody. Dzięki jego staraniom w 1901 r. na Afognaku zbudowano drewnianą kaplicę p.w. Narodzenia NMP. Duchowny współpracował $\mathrm{z}$ prasą prawosławną w USA (czasopismo Russian American Orthodox Messenger). Sprawowanie posługi kapłańskiej na Alasce było nie lado wyzwaniem. Duchowny musiał pokonywać długie odległości, by dotrzeć do odległych wsi Aleutów. Duszpasterz pracował w warunkach bardzo surowego klimatu, który coraz bardziej dawał się ze znaki jego rodzinie. W związku z tym w 1906 r. Martyszowie postanowili przenieść się na kontynent. W kolejnych latach ks. B. Martysz prowadził działalność duszpasterską w Old Forge (stan Pensylwania), Waterbury (stan Connecticut) i West Troy (stan Nowy Jork). Następnie wyjechał do Kanady, gdzie niósł posługę kapłańską w Edmonton (prowincji Alberta) i prowincji Manitoba. Jakiś czas był dziekanem Kanady zachodniej ${ }^{1}$.

\footnotetext{
Więcej zob.: J. Charkiewicz, Męczennicy XX wieku. Martyrologia Prawostawia w Polsce $w$ biografiach świętych, Warszawa 2008, s. 218$-221$.
} 
W 1912 r. rodzina Martyszów powróciła do kraju. 1 sierpnia 1912 r. objął stanowisko prefekta szkoły realnej w Sosnowcu. W wyniku wybuchu I wojny światowej i działań wojennych w 1915 r. wraz z rodziną duchowny został ewakuowany do Rosji. Najpierw zamieszkał w Moskwie, a następnie pracował jako nauczyciel religii w Wałdaju. Pobyt w ogarniętej rewolucją i wojną domową Rosji nie potrwał długo. Rodzina Martyszów postanowiła powrócić do Polski. W 1919 r. ojciec Bazyli osiedlił się w Sosnowcu, gdzie objął miejscową parafię. Z upoważnienia bpa Włodzimierza (Tichonickiego) i metropolity Jerzego (Jaroszewskiego) został administratorem cerkiewnym na terenie Chełmszczyzny ${ }^{2}$. Wkrótce popadł w konflikt z częścią parafian w Sosnowcu. Twierdził, że przyczyną niechęci żywionej względem niego przez niektórych parafian był jego negatywny stosunek do tendencji rusyfikatorskich wśród kleru prawosławnego ${ }^{3}$.

Wówczas nastąpił zwrot w karierze duchownego. W odrodzonym w $1918 \mathrm{r}$. Wojsku Polskim służyli żołnierze różnych wyznań. W celu zaspokojenia potrzeb religijnych tych ludzi w 1919 r. dowództwo wojskowe powołało duszpasterstwo wojskowe wyznań niekatolickich. W czerwcu 1919 r. duszpasterstwo wojskowe wyznań niekatolickich wyłączono spod jurysdykcji biskupa polowego. 28 czerwca 1919 r. minister spraw wojskowych gen. Józef Leśniewski wydał rozkaz o utworzeniu w ramach Departamentu I Mobilizacyjno-Organizacyjnego Sekcji Religijno-Wyznaniowej, w skład której wchodził m.in. referat wyznania prawosławnego. Zachodziła potrzeba powołania naczelnego kapelana prawosławnego. Ojciec Bazyli idealnie nadawał się na to stanowisko. W 1919 r. dwukrotnie - 11 lutego i 16 czerwca - składał podanie o przyjęcie do WP. Władze wojskowe początkowo rozważały na to stanowisko kandydaturę ks. Bazylego Markiewicza. Duchowny ten miał za sobą praktykę kapelana wojskowego w armii rosyjskiej. W latach 1906-1915 był kapelanem w twierdzy Modlin ${ }^{4}$. Niemniej jednak ks. B. Martysz nie przestawał ubiegać się o funkcję kapelana wojskowego. W liście do szefa Oddziału Mobilizacyjno-Organizacyjnego MSWojsk. mjr Bronisława Pierackiego duchowny podkreślał swój negatywny stosunek do moskalofilstwa wśród kleru prawosławnego. Prezentował siebie jako otwarcie działającego na korzyść odbudowy niepodległej Polski. O swym kontrkandydacie ks. B. Markiewiczowi pisał, że jest on „człowieka wyksztatcenia domowego (...) nie władajacego językiem polskim będacego obcokrajowcem i nie mogącego wzbudzić mitości dla Ojczyzny w sercu żotnierza polskiego wyznania prawosławnego"s. W liście do posła J. Pietczyka, duchowny skarżył się na część swoich parafian w Sosnowcu, któ-

G. Sosna, A. Troc-Sosna, Hierarchia i kler Kościoła prawosławnego w granicach II Rzeczypospolitej i Polski powojennej w XIX-XXI wieku, Ryboły 2012, s. 552.

Centralne Archiwum Wojskowe (CAW), sygn.: AP 9694, Opinia MWRiOP na temat ks. B. Martysza, 9 IX 1919 r.

4 K. Капков, Памятная книга Российского военного и морского духовентсва XIX - начала XX веков. Справочные материаль, Moskwa 2008, s. 154-155.

5 CAW, AP 9694, List ks. B. Martysza do szefa oddziału mobilizacyjnoorganizacyjnego MSWojsk. mjr Pierackiego, 17 czerwca 1919 r. rych jego zdaniem ,partia rosyjska” podjudzała przeciwko niemu ze względu na jego pochodzenie nierosyjskie i chęć pracy dla dobra kraju. W związku z powyższym uważał, że jako kapelan wojskowy będzie bardziej owocnie pracował dla Ojczyzny niż jako proboszcz cywilny parafii w Sosnowcu. Duchowny prosił o wstawiennictwo w staraniu o przyjęcie do $\mathrm{WP}^{6}$. Ministerstwo Wyznań Religijnych i Oświecenia Publicznego (MWRiOP) pozytywnie zaopiniowało wniosek ks. Martysza stwierdzając, że ,zachowanie sie duchownego prawostawnego Martysza tak pod względem prywatnym jak i politycznym jest bez zarzutu", co sprawia, że nie ma przeszkód, by powołać go do wojska7 ${ }^{7} .25$ września 1919 r. na mocy dekretu naczelnika państwa ks. B. Martysza przyjęto do WP w stopniu kapi$\operatorname{tana}^{8}$. Ksiądz B. Martysz przystąpił do pełnienia funkcji naczelnego kapelana i referenta wyznania prawosławnego przy Sekcji Wyznań Niekatolickich i Opieki nad Grobami Wojennymi MSWojsk. 30 października 1919 r. duchowny został szefem świeżo powołanego Wojskowego Urzędu Duszpasterskiego Wyznania Prawosławnego. Na ks. Martyszu spoczął główny ciężar organizacji służby duszpasterskiej wyznania prawosławnego w odrodzonym Wojsku Polskim?.

Początkowo ks. Martysz był jedynym zawodowym kapelanem wojskowym w WP. W celu zapewnienia należytej opieki duchownej żołnierzom prawosławnym należało rozbudować duszpasterstwo wojskowe. Latem $1920 \mathrm{r}$. zatrudniono w wojsku trzech kapelanów prawosławnych. Do jesieni 1920 r. w WP znajdowało się już 10 kapelanów pomocniczych wyznania prawosławnego ${ }^{10}$. Zespół kapelanów wojskowych z ks. Martyszem na czele nie mógł narzekać na brak pracy. Liczba żołnierzy polskich wyznania prawosławnego w 1919-1920 wahała się od 1500 do 3000 ludzi. Kapelani roztaczali opiekę duchowną nie tylko nad żołnierzami WP, lecz również nad jeńcami i internowanymi przebywającymi na terenie Polski. W celu organizacji życia religijnego i zaspokojenia potrzeb duchownych żołnierzy, jeńców i internowanych ks. B. Martysz dokonywał częstych inspekcji. Duchowny osobiście brał udział w zakładaniu parafii wojskowych i niesieniu posługi w obozach. Wiadomo, iż w okresie od wiosny 1920 do lipca 1921 r. odbył trzynaście podróży służbowych odwiedzając m.in. Wilno, Grodno, Białystok, Modlin, Brześć, Łuniniec, Kobryń, Równo, Krzemieniec, Lwów, Przemyśl, Pikulice, Łańcut, Kraków, Wadowice, Poznań, Strzałków, Tucholę,

\footnotetext{
CAW, sygn.: AP 9694, List ks. B. Martysza do posła na Sejmie J. Pietczyka, 20 VI 1919 r.

CAW, sygn.: AP 9694, Opinia MWRiOP na temat ks. B. Martysza, 9 IX $1919 \mathrm{r}$

8 CAW, sygn.: AP 9694 (Bazyli Martysz).

9 CAW, sygn.: I.300.20.66 Protokół z konferencji duszpasterzy wojskowych wyznania prawosławnego odbytej w dniach 25-26 października $1922 \mathrm{r}$.

10 W. Wróblewski, Duszpasterstwo mniejszości religijnych $w$ Wojsku Polskim w latach 1918-1939, [w:] Białoruś, Czechostowacja, Litwa, Polska, Ukraina. Mniejszości w świetle spisów statystycznych XIX-XX w. red.: J. Skarbka, Lublin 1996, s. 104-105; Z. Waszkiewicz, Duszpasterstwo w Siłach Zbrojnych Drugiej Rzeczypospolitej (1918-1939), Torun 2000, s. 137; J. Odziemkowski, Stużba duszpasterska Wojska Polskiego 19141945. Warszawa 1998, s. 63-65.
} 
Piotrków, Częstochowę, Sosnowiec, Aleksandrów Kujawski, Toruń ${ }^{11}$. Warto przyjrzeć się bliżej jego pracy. 25 października 1920 r. ks. B. Martysz był w szpitalu w Modlinie, a 15 grudnia złożył wizytę jeńcom w szpitalu brzeskim ${ }^{12}$. 8 lipca 1921 r. duchowy odwiedził obóz w Aleksandrowie Kujawskim, gdzie odprawił nabożeństwo w cerkwi obozowej w obecności 5 tysięcy ludzi. Naczelny kapelan prawosławny WP udzielił również pomocy $\mathrm{w}$ organizowaniu kursów kapelanów wojskowych dla żołnierzy byłej armii Ukraińskiej Republiki Ludowej (URL) w Kali$\mathrm{szu}^{13} . \mathrm{Z}$ analizy dokumentacji wojskowej wynika, że do lata 1921 r. kapelani wojskowi pod wodzą ks. B. Martysza nieśli posługę kapłańską w Warszawie, Modlinie, Łodzi, Aleksandrowie Kujawskim, Poznaniu, Tucholi, Płocku, Białymstoku, Grodnie, Krakowie, Wadowicach, Lwowie, Łańcucie, Piławach. Prowadzono również ewidencję zgonów wojskowych. W okresie od listopada 1919 do lipca 1921 r. do kancelarii ks. B. Martysza wpłynęło 7500 metryk zgonu żołnierzy, jeńców i internowanych ${ }^{14}$.

W 1919-1921 służba duszpasterska wyznania prawosławnego w WP znajdowała się w stadium rozwoju. Mimo licznych trudności spowodowanych stanem wojny udało się zorganizować sprawnie działające - jak na warunki wojenne - duszpasterstwo wojskowe, które potrafiło sprostać swemu głównemu zadaniu: zapewnieniu opieki duchownej wojskowym wyznania prawosławnego. W odniesieniu do jeńców bolszewickich znamienne było to, że na pociechę religijną nie mogli oni liczyć we własnej armii podczas gdy w niewoli zapewniono im godne warunki do organizacji opieki duszpasterskiej. Nie ulega wątpliwości, że te sukcesy w dużym stopniu należy zawdzięczać ks. B. Martyszowi ${ }^{15}$.

Dużym problemem w działalności służby duszpasterskiej w wojsku był nieuregulowany status Kościoła prawosławnego w Polsce. Do połowy lat dwudziestych pod względem organizacyjno-kanonicznym był on częścią Kościoła rosyjskiego. W sytuacji, gdy prowadzono działania wojenne, kontakty z patriarchą moskiewskim były utrudnione. Kanony kościelne nakazywały jednak uzyskania akceptacji przełożonych duchownych na działalność duszpasterską $\mathrm{w}$ wojsku. W związku z powyższym po objęciu stanowiska szefa duszpasterstwa prawosławnego ks. B. Martysz poczuł się w obowiązku zawiadomić swoich hierarchów o istnieniu duszpasterstwa prawosławnego w WP. W liście do patriarchy moskiewskiego Tichona naczelny prawosławny kapelan WP w sposób szczegółowy

\footnotetext{
CAW, sygn.: I.300.20.1, k. 198, Sprawozdanie ks. W. Martysza z działalności duszpasterstwa wyznania prawosławnego z 16 lipca $1921 \mathrm{r}$. 12 CAW, sygn.: I.300.20.64, Pismo MSWojsk. do Sekcji Wyznań Obcych, 28 IX 1920 r.

13 M. Martynowicz, Święty kapłan-męczennik Bazyli (Martysz), „Polski Żołnierz Prawosławny" 2003, nr 3, s. 3; J. Charkiewicz, Męczennicy XX wieku. Martyrologia Prawosławia w Polsce $w$ biografiach świętych, Warszawa 2008, s. 223-224.

14 CAW, , sygn.: I.300.20.1, k. 198-199, Sprawozdanie ks. B. Martysza z działalności duszpasterstwa wyznania prawosławnego z 16 lipca $1921 \mathrm{r}$. 15 Zob.: J. Grzybowski, Duszpasterstwo prawosławne w Wojsku Polskim podczas wojny z bolszewicka Rosja, 1919-1920, „Przegląd WojskowoHistoryczny" 2011, nr 4, s. 193-201.
}

informował hierarchę o organizacji duszpasterstwa wyznania prawosławnego w Wojsku Polskim i prosił o udzielenie błogosławieństwa dla swojej działalności. Duchowny zaznaczał, że $\mathrm{w}$ razie przeprowadzenia mobilizacji na ziemiach wschodnich do WP zostanie wcielonych ok. 50 tys. prawosławnych ${ }^{16}$. Naczelny kapelan prawosławny WP wystosował również list do bpa białostockiego i grodzieńskiego Włodzimierza (Tichonickiego). Ksiądz B. Martysz zwrócił się do niego jako do administratora diecezji warszawskiej i chełmskiej o zatwierdzenie go na stanowisku szefa służby duszpasterskiej w WP. Nie wiemy jednak, czy listy te dotarły do adresatów ${ }^{17}$.

Po zakończeniu działań wojennych rozpoczął się nowy etap $\mathrm{w}$ działalności ks. Martysza. Zastosowanie w województwach wschodnich II RP poboru powszechnego sprawiło, że od 1921 r. liczba żołnierzy wyznania prawosławnego znacznie wzrosła. Szacuje się, że w 19211939 odsetek prawosławnych w siłach zbrojnych II Rzeczypospolitej wahał się od 9 do $12 \%$ ogółu żołnierzy. Stanowili oni drugą co do liczebności grupę wyznaniową w WP ${ }^{18}$. Duszpasterstwo prawosławne stanęło wobec nowych wyzwań. Po przejściu wojska na stopę pokojową uległa zmianie struktura organizacyjna. W sierpniu $1921 \mathrm{r}$. utworzono Wydział Wyznań Niekatolickich (WWN), który od 1 czerwca 1927 r. zmienił nazwę na Biuro Wyznań Niekatolickich (BWN), podlegające do maja 1933 r. bezpośrednio ministrowi spraw wojskowych. W składzie tego Wydziału/Biura działał m.in. Główny Wojskowy Urząd Duszpasterski Wyznania Prawosławnego z naczelnym kapelanem prawosławnym na czele.

W okresie pokoju na ks. Martysza spłynęły kolejne awanse. 13 września 1921 r. awansował on do stopnia pułkownika, zaś 16 czerwca 1922 r. synod metropolitarny w Warszawie nadał mu godność protoprezbitera z prawem noszenia mitry, która przysługiwała kapelanom dawnej armii rosyjskiej ${ }^{19}$. Analiza źródeł archiwalnych pozwala stwierdzić, że ks. protoprezbiter B. Martysz z nawiązką podołał swoim obowiązkom naczelnego kapelana. Nie zawiódł zaufania przełożonych i w pełni wywiązywał się z powierzonym mu zadań. Okres sprawowania przez ks. Martysza funkcji naczelnego kapelana prawosławnego to czas dostosowywania służby duszpasterskiej w wojsku do warunków pokojowych, powstania stałej struktury organizacyjnej, rozbudowy duszpasterstwa. W 1925 r. pod kierunkiem ks. B. Martysza posługę kapłańską w wojsku pełniło 15 kapelanów zawodowych, w tym: 1 protoprezbiter, 3 proboszczów, 2 starszych kapelanów i 9 kapelanów. Natomiast w 1933 r. duszpasterstwo wojskowe wyznania

\footnotetext{
16 CAW, sygn.: I.300.20.49, List ks. B. Martysza do patriarchy moskiewskiego Tichona, brak daty.

17 CAW, sygn.: I.300.20.49, List ks. B. Martysza do bp białostockiego Włodzimierza, brak daty.

18 Z. Waszkiewicz, Duszpasterstwo wojskowe na terenie Dowództwa Okręgu Korpusu nr VIII w Toruniu, [w:] Mniejszości narodowe i wyznaniowe w sitach zbrojnych Drugiej Rzeczypospolitej 1918-1939. Zbiór studiów, Toruń 2001, s. 288

19 CAW, sygn.: AP 9694, List bp krzemienieckiego do MSWojsk., 25 IV $1921 \mathrm{r}$
} 
prawosławnego składało z 1 protoprezbitera, 1 dziekana, 2 starszych kapelanów i 8 kapelanów ${ }^{20}$.

Jako naczelny kapelan ks. B. Martysz często odbywał wizytację parafii wojskowych w różnych częściach kraju. Tak na przykład w lipcu 1924 r. duchowny odbył podróż do Okręgu Korpusu (OK) IV (Łódź), V (Kraków) i X (Przemyśl $)^{21}$. Szef duszpasterstwa wojskowego wyznania prawosławnego dbał o poziom pracy zespołu podległych mu kapelanów. Świadczy o tym fakt, iż 26 września 1933 r. ks. protoprezbiter B. Martysz wystosował list do dziekanów poszczególnych OK, nakazując im nadsyłanie sprawozdań ze swej działalności, które szczegółowo odzwierciedlałyby m.in. stan moralno-religijny i nastroje wśród żołnierzy. Jednocześnie prosił, by sprawozdania te były oparte „,na faktach i liczbach”, a nie stanowiły ,zbioru bezpodstawnych rozumowań" ${ }^{22}$. Pewien problem w pracy kapelanów wojskowych stanowił wpływ różnych sekt na poborowych. Naczelny kapelan nawoływał do zwalczania tego zjawiska poprzez odczyty, pogadanki i kazania okolicznościowe ${ }^{23}$. Ksiądz B. Martysz dał się poznać jako bardzo uzdolniony kaznodzieja. Wszystkie jego kazania były przepełnione patriotyzmem i miłością do Ojczyzny. Jako naczelny kapelan prawosławny WP ks. B. Martysz co roku wydawał listy pasterskie do żołnierzy z okazji świąt religijnych i państwowych ${ }^{24}$.

Przez pewien czas poważnym utrudnieniem w pracy duszpasterskiej kapelanów wyznania prawosławnego był brak modlitewnika dla żołnierzy. W związku z tym ks. Martysz postulował potrzebę wydania takiego modlitewnika ${ }^{25}$. W 1925 r. ukazał się modlitewnik dla żołnierzy prawosławnych w nakładzie 15 tys. egzemplarzy. Kolejne edycje ujrzały światło dzienne w 1930 r. i 1931 r. Pierwszy wydano cyrylicą, a drugi - alfabetem łacińskim. Modlitewnik zawierał modlitwy w języku cerkiewnosłowiańskim $\mathrm{z}$ wymową ukraińską ${ }^{26}$. Publikacja wywołała duże zainte-

20 CAW, I.300.20.57, Sprawozdanie roczne z działalności Głównego Wojskowego Urzędu Duszpasterskiego wyznania prawosławnego za rok 1925; Ibidem, Sprawozdanie roczne z działalności duszpasterskiej księdza protoprezbitera WP za rok 1930; Ibidem, Sprawozdanie roczne z działalności duszpasterskiej księdza protoprezbitera WP za rok 1932; Ibidem, Sprawozdanie roczne z działalności BWN za rok 1937.

21 CAW, sygn.: I.300.20.57, Sprawozdanie dziekanatu prawosławnego DOK IV za II półrocze 1924.; Альфа, Православная приходская община в Перемышле, „Воскресное чтение” 1926, nr 48, с. 752-754.

${ }^{22}$ CAW, sygn.: I.300.20.57, List ks. protoprezbitera WP do dziekanów prawosławnych OK I, II, III, V, VI, VII, VIII, IX w sprawie rocznych sprawozdań, 26 IX 1933 r.

${ }^{23}$ CAW, Sprawozdanie z działalności ks. protoprezbitera WP za rok 1930. 24 W jednym $\mathrm{z}$ listów pasterskich, wydanym z okazji świąt Bożego Narodzenia w 1930 r., czytamy m.in.: „Za kordonem naszego państwa rozbrzmiewaja nawolywania ludzi wrogo usposobionych do Polski (...) Ojczyzna, kochany żolnierzu, powołała Cię do obrony jej bezpieczeństwa, swobody, niepodległości i całości jej granic. (...) Stójże więc niewzruszenie na tym odpowiedzialnym posterunku, przyswajajac sobie sztuke wojskowa w tym głębokim przekonaniu, że nasz Naczelny Wódz i pierwszy marszałek Polski razem z toba bacznie czuwa nad wszelkim niebezpieczeństwem, zagrażającym naszej Ojczyźnie“. CAW, sygn.: I.300.20.75.

25 CAW, I.300.20.57, Sprawozdanie $\mathrm{z}$ działalności Głównego Wojskowego Urzędu Duszpasterskiego wyznania prawosławnego za rok 1925.

26 CAW, I.300.20.57, Sprawozdanie z działalności ks. protoprezbitera WP za rok 1930 resowanie wśród żołnierzy, do tego stopnia, że w 1932 r. naczelny kapelan prawosławny rozważał możliwość przygotowania kolejnej edycji. Podjęto przygotowania do wydania modlitewnika w języku białoruskim, jednak z braku funduszy sprawa nie posunęła się do przodu ${ }^{27}$. W tym samym czasie wydano modlitewniki żołnierskie po ukraińsku. Wydanie modlitewnika dla żołnierzy narodowości ukraińskiej było pokłosiem konferencji kapelanów odbytej pod przewodnictwem ks. B. Martysza. Ustalono, że modlitewnik będzie nosił tytuł „Druh żownira. Zbirnyk mołytw, nauk i piseń pobożnych dla prawosławnoho żownira Armii Polskoj w mowi ukraińskij ułożenyj”, będzie zawierał modlitwy codzienne, modlitwy z liturgii, troparze, skrócony katechizm oraz część historyczną i religijno-moralną. Komisja podjęła decyzję, że przy tłumaczeniu modlitw na język ukraiński należy uwzględnić prace członka komisji przy MWRiOP prof. Iwana Ohijenki, jako że dokonał on thumaczenia z oryginałów greckich ${ }^{28}$.

Dużą wagę ks. B. Martysz przywiązywał do otwierania świątyń garnizonowych. Na początku lat dwudziestych naczelny kapelan prawosławny WP kilkakrotnie interweniował u wyższych władz wojskowych w sprawie cerkwi garnizonowej w Warszawie. W garnizonie stołecznym służyło przeszło 2 tys. żołnierzy wyznania prawosławnego, którzy byli pozbawieni własnej świątyni wojskowej. Naczelny kapelan prawosławny złożył memoriał do Oddziału II Sztabu Generalnego WP, w którym skarżył się na złą sytuację żołnierzy prawosławnych garnizonu warszawskiego. Zaznaczał, że wojskowi wyznania prawosławnego gorliwie pełnią swe obowiązki wojskowe względem Ojczyzny, ale pod względem opieki duszpasterskiej czują się poszkodowani, gdyż nie mają swojej świątyni i w związku z tym kapelani wojskowi nie mogą należycie spełniać swoich obowiązków duszpasterskich. Protoprezbiter WP prosił więc władze wojskowe o przydzielenie na potrzeby wojskowego duszpasterstwa prawosławnego odpowiedniego budynku. Duchowny zabiegał o przekazanie do dyspozycji duszpasterstwa wojskowego wyznania prawosławnego byłej rosyjskiej cerkwi garnizonowej św. Piotra i Pawła (na Mokotowie). Starania te nie przyniosły jednak oczekiwanych rezultatów. Urządzono więc kaplicę św. Mikołaja $\mathrm{w}$ drewnianym pomieszczeniu na terenie koszar przy ul. Ratuszowej, w której ks. Martysz regularnie odprawiał nabożeństwa dla żołnierzy ${ }^{29}$. Erygowano również kilka świątyń wojskowych poza Warszawą. Tak na przykład 6 marca 1927 r. w obecności innych kapelanów, przedstawicieli władz wojskowych i państwowych ks. Martysz dokonał poświęcenia kaplicy wojskowej w garnizonie krakowskim $^{30}$. Naczelny kapelan WP wyznania prawosławnego

\footnotetext{
${ }^{27}$ CAW, sygn.: I.300.20.57, Sprawozdanie z działalności ks. protoprezbitera WP za rok 1930; Ibidem, Sprawozdanie z działalności duszpasterskiej ks. protoprezbitera WP za rok 1932.

28 CAW, sygn.: I.300.20.66, Protokół konferencji kapelanów wyznania prawosławnego w sprawie wydania modlitewnika dla użytku żołnierzy, brak daty.

29 J. Grzybowski, W stużbie Rzeczypospolitej. Duszpasterstwo wojskowe wyznania prawosławnego w Wojsku Polskim w latach 1919-1949, Warszawa 2016, s. 161-173.

30 CAW, sygn.: I.300.20.57, Sprawozdanie dziekanatu prawosławnego
} 
zajmował się również sprawami personalnymi: rozpatrywał kandydatury duchownych ubiegających się o przyjęcie do WP, zatrudniał nowych i zwalniał starych kapelanów. Duchowny interweniował także w razie nieporozumień i sytuacji konfliktowych. Tytułem przykładu można przytoczyć sprawę ks. Konstantego Siemaszkę, dziekana OK $\mathrm{V}$ w Krakowie, któremu przedstawiciele miejscowego duchowieństwa rzymskokatolickiego zarzucili rzekome uprawianie propagandy religijnej wśród żołnierzy wyznania katolickiego. Dochodzenie dowiodło, że zarzuty pod adresem duchownego były pozbawione wszelkich podstaw $^{31}$.

W okresie międzywojennym władze II RP podejmowały próby polonizacji prawosławia ${ }^{32}$. Kwestią drażliwą była sprawa kalendarza liturgicznego. Władze usiłowały zastąpić w życiu Kościoła kalendarz juliański kalendarzem gregoriańskim, który wówczas był wprowadzany w niektórych autokefalicznych kościołach prawosławnych. Pomysł ten forsowano przede wszystkim w wojsku. Naczelny kapelan prawosławny był związany przysięgą wojskową i musiał karnie stosować się do zaleceń swoich przełożonych. W grudniu 1924 r. po raz pierwszy odczytano list pasterski ks. protoprezbitera WP, który składał żołnierzom życzenia bożonarodzeniowe według nowego stylu $^{33}$. Wprowadzenie kalendarza gregoriańskiego rodziło w wojsku wiele dotkliwych problemów. Sprawa kalendarza w życiu żołnierza wiązała się z udzielaniem urlopów na wyjazd do rodzin i zwalnianiem od pełnienia służby. W związku z powyższym naczelny kapelan apelował do dowództwa, by na święta obchodzone według kalendarza gregoriańskiego bezwarunkowo udzielano urlopów żołnierzom wyznania prawosławnego, gdyż w przeciwnym razie może to podważyć wśród wiernych tezę o celowości wprowadzenia nowego stylu ${ }^{34}$.

Ojciec Bazyli uczestniczył w życiu Kościoła prawosławnego w Polsce. Wspomagał metropolitę Jerzego (Jaroszewskiego), a potem Dionizego (Waledyńskiego) w przygotowywaniu gruntu pod ogłoszenie autokefalii Kościoła prawosławnego w Polsce, co stało się faktem w 1925 r. $\mathrm{Na}$ osobną uwagę zasługują stosunki naczelnego kapelana WP z metropolitą Dionizym. Na relacje między naczelnym kapelanem wojskowym i zwierzchnikiem PAKP wywierała wpływ polityka państwa wobec prawosławia. W okre-

przy DOK V za 1927.

31 CAW, sygn.: I.300.20.11, List ks. B. Martysza do szefa BWN, 1 VI $1928 \mathrm{r}$.

32 Politykę państwa wobec Kościoła prawosławnego w okresie międzywojennym badali m.in. M. Papierzyńska-Turek, A. Mironowicz, E. Mironowicz, G.J. Pelica. Wśród najważniejszych prac współczesnych badaczy należy przede wszystkim wymienić: M. Papierzyńska-Turek, Między tradycja a rzeczywistością. Państwo wobec prawosławia 19181939, Warszawa 1989; A. Mironowicz, Kościół prawosławny w Polsce, Białystok 2006; G.J. Pelica, Kościót prawosławny w województwie lubelskim (1918-1939), Lublin 2009.

33 CAW, sygn.: I.300.20.57, Sprawozdanie dziekanatu prawosławnego OK IV za II półrocze $1924 \mathrm{r}$.

34 CAW, sygn.: I.300.20.57, Sprawozdanie dziekanatu prawosławnego OK IV za I półrocze 1924 r.; Ibidem, Sprawozdanie dziekanatu prawosławnego OK IV za II półrocze 1924 r.; Ibidem, Sprawozdanie dziekanatu prawosławnego OK VI za II półrocze $1924 \mathrm{r}$. sie międzywojennym (do końca 1938 r.) status Kościoła prawosławnego w Polsce nie był prawnie uregulowany, co rzutowało na funkcjonowanie duszpasterstwa wojskowego. Między wojskiem i hierarchią kościelną toczyła się dyskusja o zwierzchnictwo nad duszpasterstwem wojskowym. Metropolita Dionizy postulował potrzebę współdecydowania głowy Kościoła prawosławnego w sprawach dotyczących duszpasterstwa wojskowego. Zwierzchnik PAKP stał na stanowisku, że wszystkie nominacje, przeniesienia i zwolnienia kapelanów wojskowych, włącznie $\mathrm{z}$ protoprezbiterem, powinny być dokonywane przez metropolitę po bezpośrednim porozumieniu z ministrem spraw wojskowych. Władyka uważał, że wszystkie zarządzenia wydawane kapelanom wojskowym w kwestiach dotyczących pracy duszpasterskiej protoprezbiter WP musi przedkładać metropolicie, zaś co roku naczelny kapelan ma obowiązek składać zwierzchnikowi PAKP sprawozdanie roczne z działalności duszpasterskiej w wojsku. Wszelkiej ingerencji władz kościelnych w sprawy wojska były natomiast przeciwne czynniki wojskowe. Władze wojskowe i kościelne różniły się w kwestii uprawnień i podległości naczelnego kapelana. 14 grudnia 1929 r. Synod Biskupów PAKP opracował „Instrukcję dla duchowieństwa prawosławnego WP'. Zgodnie z tym dokumentem protoprezbiter nie miał uprawnień do wykonywania - w stosunku do podległego mu duchowieństwa wojskowego - funkcji, które według kanonów kościelnych przysługują wyłącznie biskupowi diecezjalnemu (np. prawo do mianowania, przeniesienia lub odwołania kapelanów) ${ }^{35}$. Ksiądz B. Martysz zaprotestował przeciwko wspomnianej instrukcji. Uważał, że dokument jest sprzeczny z obowiązującymi w wojsku przepisami i że jego wdrożenie w życie poskutkuje wieloma komplikacjami ${ }^{36}$. Z kolei władze wojskowe zamierzały wykorzystać naczelnego kapelana prawosławnego WP do wywierania wpływu na hierarchię prawosławną. W związku z tym postulowano potrzebę doprowadzenia do większej niezależności naczelnego kapelana prawosławnego WP od metropolity. W kręgach wojskowych zrodził się nawet pomysł uzyskania od hierarchii kościelnej zgody na udział naczelnego kapelana w posiedzeniach Synodu Biskupów ${ }^{37}$. Posunięcie takie było przejawem braku zaufania do wyższej hierarchii Kościoła prawosławnego. Wychodzono z założenia, że związany przysięgą wojskową i podległy rozkazom swoich wojskowych przełożonych naczelny kapelan WP mógłby oddziaływać na władze kościelne w kie-

\footnotetext{
35 CAW, sygn.: I.300.20.66, Uchwała Synodu Biskupów PAKP z 14 XII 1929 r. o instrukcji kanonicznej dla duchowieństwa prawosławnego WP. 36 Protoprezbiter WP pisał m.in.: „Instrukcja ta zawiera bardzo mało przepisów kanonicznych, natomiast zasadniczo wkracza $w$ dziedzine administracji wojskowej. Sprzeciwia sie ona ustawie o podstawowym obowiązu i prawach oficerów WP z 23 III 1922 r., organizacji stużby duszpasterskiej wyznania prawosławnego i rozkazom wojskowym o subordynacji i drodze stużbowej. Wprowadzenie $w$ życie wspomnianej instrukcji, wedtug mego zdania, wywołałoby rozprężenie $i$ dezorganizacje wśród wojskowego duchowieństwa prawosławnego, uniemożliwiłoby protoprezbiterowi należyte kierownictwo duszpasterstwem i szkodliwie odbiłoby się na interesach wojska“. CAW, sygn.: I.300.20.50, List ks. B. Martysza do MSWojsk, 14 XII $1929 \mathrm{r}$.

37 CAW, sygn.: I.300.1.404, List ministra spraw wojskowych do metropolity Dionizego, 7 I $1931 \mathrm{r}$.
} 
runku zgodnym z oczekiwaniami władz. Ksiądz Martysz znalazł się w dość niezręcznej sytuacji. Duchowny musiał wykazać się daleko idącym taktem i dyplomacją, by z jednej strony nie narazić się swoim przełożonym wojskowym, z drugiej zaś dochować lojalności i posłuszeństwa wobec zwierzchnika kościelnego. W związku z tym był krytykowany przez obie strony. Niekiedy naczelny kapelan doświadczał chłodnego przyjęcia metropolity Dionizego. Miała miejsce sytuacja, kiedy władyka zażądał od ks. Martysza, by ten podczas audiencji u metropolity miał na sobie strój kapłana zamiast munduru wojskowego. Tymczasem, przedstawiciele władz wojskowych zarzucali ks. Martyszowi zbytnią uległość wobec metropolity Dionizego ${ }^{38}$.

W czasie pełnienia funkcji naczelnego kapelana WP ks. B. Martysz cieszył się pochlebną opinią niemal wszystkich swoich przełożonych w wojsku. W 1922 r. płk Bronisław Pieracki w ten oto sposób charakteryzował ks. Martysza: ,jako naczelny kapelan wyznania prawostawnego WP oddaje dzięki swojemu sprytowi i wyrobieniu politycznemu opartemu na gtębokim przemyśleniu ustosunkowania się narodowości kresowych do Rzeczypospolitej Polskiej wprost nieoceniane ustugi” ${ }^{39}$. Płk Dąbrowski, który jako bezpośredni przełożony obserwował pracę naczelnego kapelana, zaznaczał m.in.: „Lojalność wobec Rzeczypospolitej Polskiej $i$ wtadz wojskowych bez zarzutu. Jako naczelny kapelan - zapobiegliwy $i$ dbaty o podwtadnych. Dużo ambicji i samodzielności. Narzucać obcej woli (ks. metropolity) nie pozwala. Sporo dyplomacji. Dużo taktu życiowego. Często przesadna ostrożność w wypowiedzeniu swego zdania wobec zwierzchności wojskowej. Na stanowisku kierowniczym dużo inicjatywy i energii. Pracownik bardzo solidny i punktualny" ${ }^{40}$. Zupełnie inaczej duchowny był postrzegany przez kolejnego szefa BWN ppłk Kuczyńskiego, który w 1928 r. w opinii dotyczącej ks. Martysza napisał m.in.: ,ks. protoprezbiter Martysz Bazyli - człowiek o wybitnie rosyjskiej psychice. Dawny bojownik Autokefalii Kościoła prawostawnego w Polsce-obecnie ulega catkowicie wptywom obecnego metropolity Dionizego i jego moskalofilskiego otoczenia. Sprawę własnej kariery duchownej stawia wyżej ponad interes państwa. Z tego powodu na stanowisku naczelnego kapelana wydziatu prawostawnego $w$ BWN nie nadaje sie, jednak na razie musi być tolerowany z powodu braku zamiennika. Chytry - dosyć ograniczony - cierpi na zanik pamięci, wskutek czego się często kompromituje. Do żadnej pracy twórczej nie nadaje się-ledwie dostateczny z konieczności" ${ }^{\text {"41 }}$. Po upływie

\footnotetext{
38 Wymownie zobrazuje to opinia szefa BWN płk Krawczyka na temat działalności ks. B. Martysza za rok 1933, w której czytamy m.in.: ,, ostatnio daja się zauważyć tendencje do zbliżenia do metropolity Dionizego przy jednoczesnym niepodtrzymywaniu ścistej taczności z bardziej czynnymi pracujacymi intensywnie propaństwowo jednostkami podległego sobie duchowieństwa wojskowego". CAW, sygn.: AP 12471, Roczna opinia płk Krawczyka dotycząca ks. B. Martysza, 1933 r.

${ }^{39}$ CAW, sygn.: AP 9694, Opinia płk B. Pierackiego na temat ks. B. Martysza, $1922 \mathrm{r}$.

40 CAW, sygn.: AP 9694, Opinia płk Dąbrowskiego na temat ks. B. Martysza, $1925 \mathrm{r}$.

41 CAW, sygn.: AP 9694, Opinia ppłk Kuczyńskiego na temat ks. B. Martysza, $1928 \mathrm{r}$.
}

roku tenże kierownik BWN nie zmienił swego mniemania na temat podkomendnego pisząc o nim, co następuje: „uległ catkowicie wplywowi moskiewskiego otoczenia metropolity Dionizego. Prace nad urabianiem szeregowych wyznania prawosławnego $w$ duchu państwowości polskiej stara się hamować. Staje się więc na stanowisku naczelnego kapelana wyznania prawostawnego w BWN wręcz szkodliwym. Ocena ogólna: dostateczny. Dla dobra państwa należaloby go zwolnić na emeryturę"42. Krytyczną ocenę wystawioną przez ppłk Kuczyńskiego trudno uznać za rzetelną i bezstronną, ponieważ u jej podstaw leżała osobista niechęć, którą szef BWNżywił względem swojego podwładnego. Na rzecz tego twierdzenia przemawia fakt, że ppłk Kuczyński był odosobniony w swoich sądach na temat ks. Martysza. Opinii ppłk Kuczyńskiego nie podzielał jego następca na stanowisku kierownika BWN płk Krawczyk, który nie szczędził pochwał dla ks. protoprezbitera B. Martysza: „Spokojny, taktowny, ostrożny. O potrzeby swego wyznania $i$ wyznawców stużacych $w$ wojsku dbaty. Obowiazki swoje spetnia sumiennie. Bardzo do$b r y^{\prime \prime 43}$. W następnym latach przełożeni równie pochlebnie wypowiadali się na temat naczelnego kapelana wyznania prawosławnego. Prawdziwość tych opinii potwierdzają odznaczenia i pochwały, którymi był wyróżniany ks. B. Martysz. 20 listopada 1922 r. kierownik Wydziału Wyznań Niekatolickich (BWN) postawił wniosek o odznaczenie duchownego Złotym Krzyżem Zasług. W tym dokumencie czytamy m.in.: ,zwolennik realnie podjętej pracy dla państwa polskiego jako naczelny kapelan wyznania prawostawnego zorganizowat duszpasterstwo tego wyznania na zdrowych podstawach, których głównym zadaniem jest urobienie żotnierza prawostawnego na dobrego i lojalnego obywatela i obrońce Rzeczypospolitej. Zdolny, pracowity, sumienny i obowiazkowy, polożyt wielkie zastugi na polu pracy duszpasterskiej, wykazujac troskliwa opiekę nad zotnierzami prawostawnymi, zapewniajac im szanse zaspokojenia wszystkich potrzeb duchownych (...) dzięki taktowi i umiejętności w utrzymaniu stosunków $i$ wspótpracy z innymi wyznaniami usuwat wszelkie możliwości nieporozumień wyznaniowych na tle armii”"44. W dowód uznania zasług w wojsku w 1923 r. duchowny został odznaczony Orderem Odrodzenia Polski. 10 grudnia 1925 r. ks. B. Martysz świętował 25-lecie swego kapłaństwa. W liście gratulacyjnym od ówczesnego ministra spraw wojskowych gen. Lucjana Żeligowskiego czytamy m.in.: „ks. protoprezbiter Martysz (...) zawsze przywiazany do swej Ojczyzny (...) i dzielnie przeciwstawiat się wszelkim nieżyczliwym jej pradom. Tych zasad przestrzegat tez ks. Martysz przy organizowaniu duszpasterstwa prawostawnego $w$ Wojsku Polskim, opierajac je na zdrowych podstawach (...) Zalety tego wybitnie zdolnego, sumiennego, obowiazkowego pracownika, cała dusza oddanego państwowości polskiej

42 CAW, sygn.: AP 9694, Opinia ppłk Kuczyńskiego na temat ks. B. Martysza, 1929 r.

43 AAN, MWRiOP, t. 1237, k. 150; CAW, sygn.: AP 9694, Opinia płk Krawczyka na temat ks. B. Martysza, 1930 r.

44 CAW, sygn.: AP 9694, Wniosek szefa BWN w sprawie odznaczenia ks. B. Martysza Złotym Krzyżem Zasług, 20 XI 1922 r. 
znalazły wyraz $w$ wysokim odznaczeniu go orderem „Odrodzenia Polski'"',45.

31 maja 1934 r. ks. B. Martysz został przeniesiony w stan spoczynku. 27 maja 1934 r. duchowny przekazal swoje pełnomocnictwa st. kapelanowi ks. Szymonowi Fedorońce. Po odejściu z wojska ks. B. Martysz osiedlił się w rodzinnym Teratynie, gdzie spędził ostatnie lata życia. Szczęśliwie przeżył wojnę i okupację, lecz został bestialsko zamordowany we własnym domu w Wielki Piątek 4 maja 1945 r. Okoliczności męczeńskiej śmierci ojca Bazylego wymagają głębszych badań. $Z$ dużą dozą prawdopodobieństwa można przyjąć, że zbrodnia ta miała związek z bratobójczymi walkami polsko-ukraińskimi, które wówczas odbywały się na tym obszarze. W październiku 1963 r. doczesne szczątki ks. B. Martysza przeniesiono na cmentarz prawosławny w Warszawie. Na początku 2003 r. dokonano ekshumacji i złożono je w cerkwi św. Jana Klimaka w Warszawie. Uchwałą Św. Synodu PAKP z 20 marca 2003 r. ks. B. Martysz został zaliczony do grona świętych i włączony do Soboru Świętych Męczenników Ziemi Chełmskiej i Podlaskiej. Uroczystości kanonizacyjne odbyły się 7-8 czerwca 2003 r. w Chełmie. Św. męczennik Bazyli Martysz został również duchownym patronem Prawosławnego Ordynariatu Wojska Polskiego ${ }^{46}$.

\footnotetext{
45 Cyt. za: P. Chomik, Naczelny kapelan wyznania prawosławnego ks. protoprezbiter Bazyli Martysz, „Polski Żołnierz Prawosławny” 1996, nr 1, s. 13; Archiwum Akt Nowych (AAN), sygn.: 14, t. 1237, k. 150, Projekt pochwały ks. B. Martysza, brak daty.

46 J. Charkiewicz, Męczennicy XX wieku. Martyrologia Prawostawia w Polsce w biografiach świętych, Warszawa 2008, s. 216-227; M. Martynowicz, Święty kapłan - męczennik Bazyli (Martysz), „Polski Żołnierz Prawosławny” 2003, nr 3, s. 3; K. Mazurek, Chetmszczyzna - , mała ojczyzna” swiaszczennomuczenika Bazylego Martysza, „Polski Żołnierz
}

Podsumowując należy stwierdzić, że ks. B. Martysz wyniósł z wojska opinię niestrudzonego sumiennego kapelana i wzorowego oficera. Był utalentowanym kaznodzieją i znakomitym organizatorem. Nie ulega wątpliwości, że duchowny pozostawił po sobie bardzo dobrą pamięć na kartach dramatycznej historii Polski XX wieku. Sumiennym pełnieniem obowiązków duszpasterskich w wojsku zaskarbił przychylność zarówno przełożonych, jak i zwykłych żołnierzy. Położył duże zasługi dla sprawy zachowania i pielęgnowania tradycji prawosławnej w wojsku. Ojciec Bazyli należał do grona ludzi, którzy bez reszty poświęcili się służbie na rzecz Ojczyzny i Kościoła. Wyznawane przez siebie wartości ojciec Bazyli wpoił swoim dzieciom $^{47}$. Życie i męczeńska śmierć kapelana stanowi przykład nieskazitelnej postawy zarówno duszpasterskiej, jak i żołnierskiej.

Prawosławny" 2007, nr 3, s. 17.

47 Tytułem przykładu należy przytoczyć los Bazylego Martysza-juniora (ur. 1906 r.), który idąc w ślady ojca związał swój los z mundurem oficera WP. Jako lekarz weterynarii i absolwent Szkoły Podchorążych Rezerwy od 1935 r. wstąpił do wojska. W stopniu porucznika służył w 3 Pułku Szwoleżerów Mazowieckich. W składzie tej jednostki walczył w kampanii 1939 r., w tym w bitwie pod Kockiem. Dostał się do niewoli sowieckiej i został osadzony w obozie w obwodzie archangielskim. W 1941 r. wstąpił do Armii Polskiej pod dowództwem gen. W. Andersa. W szeregach 2 Korpusu przeszedł szlak bojowy we Włoszech. Po wojnie brał udział w życiu polonijnym i kombatanckim. Wziął udział w założeniu w Londynie w 1948 r. Zrzeszenia Prawosławnych Polaków Zagranicą (Polish Orthodox Assotiation Abroad). Później wyemigrował do Kanady, gdzie zmarł w 1979 r. Archiwum Instytutu Polskiego i Muzeum im. gen. Sikorskiego (AIPMS), sygn.: A.11/1483, Protokół zebrania komitetu organizacyjnego Zrzeszenia Prawosławnych Polaków Zagranicą, 12 VI 1948.

\section{Bibliografia}

\section{Źródła archiwalne}

Archiwum Akt Nowych, Zespół: Ministerstwo Wyznań Religijnych i Oświecenia Publicznego (sygn. 14), nr teczki: 1237.

Archiwum Instytutu Polskiego i Muzeum im. gen. Sikorskiego, Zespół: Ministerstwo Spraw Zagranicznych (sygn.: A.11), nr teczki: 1483.

Centralne Archiwum Wojskowe, Zespół: Akta Personalne (sygn.: AP), nr teczek: 9694, 12471.

Centralne Archiwum Wojskowe, Zespół: Biuro Wyznań Niekatolickich Ministerstwa Spraw Wojskowych 1919-1939 (sygn.: I.300.20), nr teczek: 1, 11, 49, 64, 66, 57, 75 .

\section{Literatura}

Charkiewicz J., Męczennicy XX wieku. Martyrologia Prawosławia $w$ Polsce $w$ biografiach świętych, Warszawa 2008.

Chomik P., Naczelny kapelan wyznania prawostawnego ks. protoprezbiter Bazyli Martysz, „Polski Żołnierz Prawosławny” 1996, nr 1, s. 13.

Grzybowski J., Duszpasterstwo prawosławne w Wojsku Polskim podczas wojny z bolszewicka Rosją, 1919-1920, „Przegląd Wojskowo-Historyczny” 2011, nr 4, s. 193-201.
Grzybowski J., W stużbie Rzeczypospolitej. Duszpasterstwo wojskowe wyznania prawosławnego $w$ Wojsku Polskim w latach 1919-1949, Warszawa 2016.

Martynowicz M., Święty kapłan - męczennik Bazyli (Martysz), „Polski Żołnierz Prawosławny” 2003, nr 3, s. 3.

Mazurek K., Chetmszczyzna - „mała ojczyzna” swiaszczennomuczenika Bazylego Martysza, „Polski Żołnierz Prawosławny" 2007, nr 3, s. 17.

Mironowicz A., Kościót prawosławny w Polsce, Białystok 2006.

Odziemkowski J., Stużba duszpasterska Wojska Polskiego 1914 1945, Warszawa 1998.

Papierzyńska-Turek M., Między tradycja a rzeczywistością. Państwo wobec prawostawia 1918-1939, Warszawa 1989.

Pelica G.J., Kościót prawosławny w województwie lubelskim (1918-1939), Lublin 2009.

Sosna G., Troc-Sosna A., Hierarchia i kler Kościoła prawosławnego w granicach II Rzeczypospolitej i Polski powojennej w XIX-XXI wieku, Ryboły 2012.

Waszkiewicz Z., Duszpasterstwo w Siłach Zbrojnych Drugiej Rzeczypospolitej (1918-1939), Torun 2000.

Waszkiewicz Z., Duszpasterstwo wojskowe na terenie Dowódz- 
twa Okręgu Korpusu nr VIII w Toruniu, [w:] Mniejszości narodowe $i$ wyznaniowe $w$ siłach zbrojnych Drugiej Rzeczypospolitej 1918-1939. Zbiór studiów, red.: W. Rezmer i Z. Karpus, Toruń 2001, s. 255-324.

Wróblewski W., Duszpasterstwo mniejszości religijnych w Wojsku Polskim w latach 1918-1939, [w:] Białoruś, Czechosłowacja, Litwa, Polska, Ukraina. Mniejszości w świetle spisów statystycznych XIX-XX w., red.: J. Skarbka, Lublin 1996, s. 104-105.

Альфа, Православная приходская община в Перемьиле, „Воскресное чтение” 1926, nr 48, с. 752-754.

Капков К., Памятная книга Российского военного и морского духовенства XIX - начала XX веков. Справочные материаль, Москва 2008.

Rozmiar artykułu: 1,07 arkusza wydawniczego 


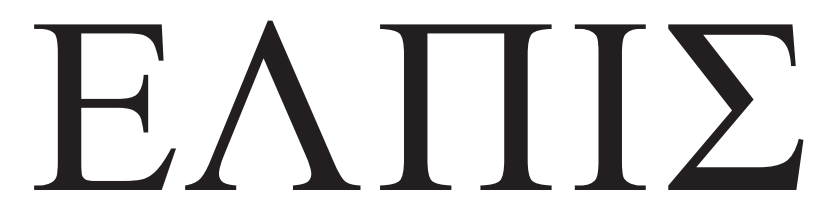

CZASOPISMO TEOLOGICZNE KATEDRY TEOLOGII PRAWOSŁAWNEJ UNIWERSYTETU W BIAŁYMSTOKU

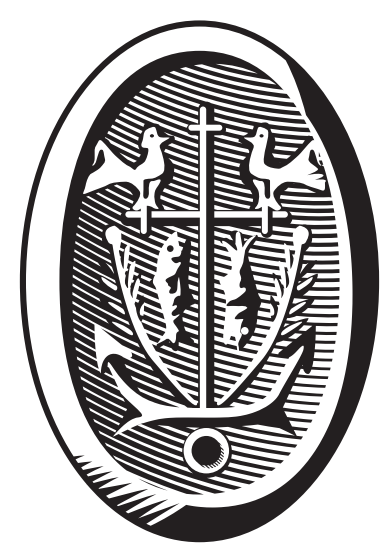

ADRES REDAKCJI

ul. Ludwika Zamenhofa 15, 15-435 Białystok, Polska tel. 85 745-77-80, e-mail: elpis@uwb.edu.pl www.elpis.uwb.edu.pl 